\title{
Development of Online-Based Learning Using Moodle E-learning System in New Innovation and Paradigm of Education Course
}

\author{
Connie*, Eko Risdianto and Meizul Zuki
}

\author{
Faculty of Teacher Training and Education, University of Bengkulu \\ *Corresponding author. E-mail: connienurmatias@yahoo.com
}

\begin{abstract}
This study aims to develop online-based learning to improve learning outcomes and student motivation in the Innovation and New Education Paradigm courses. The Moodle-based e-learning system at Bengkulu University, which is provided to facilitate online lectures, has not been maximally utilized by lecturers. In the era of the Industrial Revolution 4.0, online-based learning is urgently needed to continue to be developed in order to improve digital literacy skills and make it easy for students to study anywhere and anytime as long as there is an internet network. This study uses the Research and Development (RnD) method using the ADDIE Model. The learning method used is blended learning with flip classroom type. The limited trial was carried out by taking the research subjects of 10 students who took the innovation and New Paradigm Education courses. The research instruments were tests (pretest and posttest) and a questionnaire on learning motivation obtained through evaluation for eight meetings. The results showed a significant increase in learning outcomes and learning motivation using blended learning type flip classroom learning. This is indicated by the average $\mathrm{N}$-gain score in the Medium category. Based on the parametric statistical test, it was found that there were significant differences in the results of the pre-test and post-test $(\alpha=0.02<0.05)$. So it can be concluded that the type of flip classroom blended learning can improve student learning outcomes and learning motivation.
\end{abstract}

Keywords: E-learning, Learning outcomes, Learning motivation, Moodle.

\section{INTRODUCTION}

Symptoms of the industrial transformation 4.0 in the education sector itself, we have many sources or learning content in any field that can be easily accessed, for free via an internet connection anytime and anywhere. Several start-ups in Indonesia in the education sector have seen opportunities in this field of education, for example: ruangguru.com, quiper.com and outside Indonesia there are Khan Academy, Byjus and many more. The teachers' room in 2017 noted that the users had recorded more than 6 million users and it is still growing today. Statistical data on the number of students in Indonesia Elementary Schools, Junior High Schools and Senior High Schools are approximately 25 million students (source: http://statistik.data.kemdikbud.go.id/). This means that the users of the teacher room account for almost 25 percent of the total students in Indonesia. In the next few years this learning system will replace the conventional tutoring model [1].

Why is this educational startup now a favorite? This of course cannot be separated from the unmet needs of students at school and also what they offer by service providers, namely ease of access (can be accessed anytime and anywhere), flexible (can adjust to the material), and the price offered is relative cheaper. They want another learning model that is different from conventional learning models that are still happening today. In the future, more technologybased learning models will emerge with better model variations. The key is the best service. So here we can see a shift in the learning model desired by the user (student). This means a challenge for teachers in the era of the industrial revolution 4.0 to be able to change their learning strategies and models in accordance with the demands of contemporary developments and technology. From the description above, we can see that technology is transformed as well as the world of education. This change has resulted in many improvements and shifting roles, including in the world of education [2].

The very rapid changes that occur in the era of disruption in the 4.0 system and educational needs must also be followed by changes in processes and results that are fast and also of high quality. The demand for quality education in question is learning that is able to produce graduates who are responsible and able to ethically face the challenges of the times 
[1]. To answer this, it is deemed necessary for a system management that takes into account the various components of education. One of the learning alternatives that is able to answer the above problems is online learning. Online Learning System (online) is an implementation of online distance education which aims to increase equitable access to quality learning. Currently, Bengkulu University already has a Moodle-based e-learning system which can be accessed through the address www.elearning.unib.ac.id. However, currently not all lecturers in Bengkulu University have used this facility to be used as an alternative to online learning. This year, the university is targeting that $20 \%$ of the total lecturers in Bengkulu University must use this e-learning system.

The problems in this research, namely: How to Develop Online Learning based on the Moodle Elearning System of Bengkulu University in the Innovation and New Paradigm of Education Subject in the Education Management Postgraduate Program of Bengkulu University? Are there differences in learning outcomes through online learning based on the Moodle University of Bengkulu E-learning System in the Innovation Subject? The purpose of this research and development is to develop Online Learning based on the Moodle E-learning System of the University of Bengkulu in the Innovation and New Paradigm of Education Subject in the Education Management Postgraduate Program of the University of Bengkulu and to see differences in learning outcomes and learning motivation pre-test and posttest with based Online Learning of Moodle Elearning system.

\section{METHODS}

This research uses a type of research and development or Research and Development (R\&D). According to [2] R \& D is research that is used to be able to produce certain products, and to test the effectiveness of these products so that they can function widely, research is needed to test the effectiveness of these products. The research to be carried out is in the form of a Blended learning model product for S2 MAP Education students at the University of Bengkulu on innovation and educational paradigm courses. This study will use the steps of the development model of the instructional design model ADDIE, ADDIE stands for Analysis, Design, Develop, Implementation, Evaluations. According to product development steps, this research and development model is more rational and more complete than the 4D model [3]. Another advantage is that this model is simple and easy to learn and its systematic structure. It is simple and systematically structured, so this design model will be easily studied by educators. Implementation of learning syntax using online learning based on the Moodle e-learning system, University of Bengkulu (elearning.unib.ac.id)
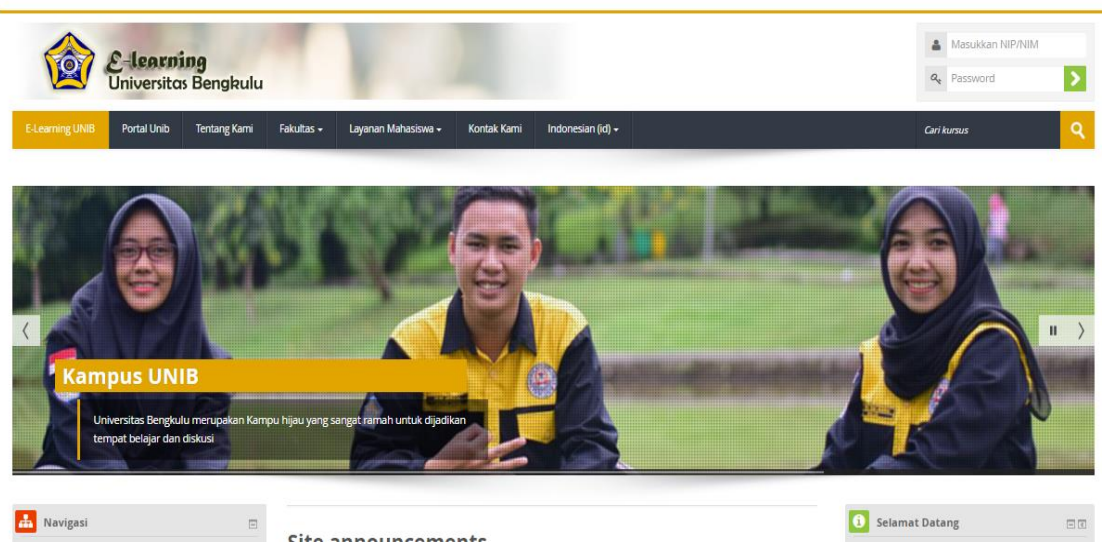

Figure 1. Sistem Elearning Unib berbasis Moodle

Data analysis of the pre-test and post-test learning outcomes to determine the Gain value in the study using the normalized gain technique [4].

$$
\mathrm{g}=\frac{S_{-S_{0}}}{S_{\text {maks }-S_{0}}}
$$

Information:
$\mathrm{S}=$ Total score on the final test, $\mathrm{S} 0=$ Total score on initial test, S_maks = Maximum score possible to achieve

In order to find out the increase in understanding of Learning Innovation and New Education Paradigms for students that occur before and after learning using online learning based on the Moodle 
e-learning system can be done using the $\mathrm{N}$-gain formula, it can be seen how much increase in student understanding of Innovation learning and the New Education Paradigm. The criteria for the $\mathrm{N}$-gain level according to [5] are as follows:

Table 1. N-Gain score

\begin{tabular}{|c|c|}
\hline Value of N-gain & Level \\
\hline $\mathrm{g} \geq 0,7$ & High \\
\hline $0,3 \leq \mathrm{g} \leq 0,7$ & Moderate \\
\hline $\mathrm{g}<0,3$ & Low \\
\hline
\end{tabular}

\section{RESULTS AND DISCUSSION}

\section{Results}

Blended learning is a combination of face-toface learning and uses online learning using the webbased Moodel system. In research, educational paradigm and innovation subjects are the subjects chosen to be the subjects that are tested to be applied to the blended learning model. This study uses the RnD method by adapting the ADDIE model resulting from the development of this research product following the stages contained in this model. The following are the stages in the process of this research [6]

Analysis Stage: This stage is a stage to identify and identify what problems are contained in the innovation course and the new educational paradigm. Based on problem identification and the content of the course, it is very appropriate if it is chosen to be applied online seeing the characteristics of students who come from various regions. Of course, the application of this learning will not be entirely online but can be presented in a blended learning (mixed) manner.

Design Stage: This stage includes the initial design to the end of the learning through the blended learning model. This material is collaborated through blended or mixed learning (face-to-face and online). The steps taken in the design process are designing the materials to be presented in the form of videos, images, content that is useful to help and strengthen student understanding. Furthermore, designing learning evaluation and designing learning time are necessary.

Development stage: The blended learning process is carried out using the flipped classroom type (modified flip classroom). Online Learning: Students learn independently to access lecture material that has been presented by the lecturer online. Students do the pretest given. The pretest is given to find out the initial knowledge before attending lectures. This pretest quiz has a password that is intended to open and start Pretest. Besides holding discussions during class meetings, students conduct online discussions in the online forums that have been provided. Lecturers provide responses from the results of the discussions conducted. Students were given assignments online and collect the task data in the form of files through the elearning. The lecturer provides an evaluation at the end of the subject. By using the blended learning model, lecturers provide opportunities for students to study independently by accessing learning materials that have been provided online anytime and anywhere. Lecturers in this model are more likely to act as facilitators and guide students to build knowledge either face-to-face or online. The design of this blended learning model can be carried out well if there are supporting facilities such as wellstructured learning materials / resources, supporting facilities such as good internet networks and devices for accessing online and offline learning such as mobile devices (cellphones), computers or laptop that is no less important in the design of this model is the need for a good evaluation system.

Implementation Stage: At this stage the lecturer conducts a trial phase of learning activities on the innovation and educational paradigm subjects. Learning is carried out in a blended manner, namely learning a mixture of face-to-face and online.

Evaluation Stage: At this stage an evaluation is carried out. Pretest Results using the E-learning System and Descriptive Statistical Analysis Data are shown below.

Table 2. Paired Samples Statistics

\begin{tabular}{|rr|r|r|r|r|}
\hline & & Mean & $\mathrm{N}$ & Std. Deviation & \multicolumn{2}{|c|}{ Std. Error Mean } \\
\hline \multirow{2}{*}{ Pair 1 } & Pretest & 46,5000 & 10 & 22,61391 & 7,15115 \\
& Postest & 80,0000 & 10 & 9,42809 & 2,98142 \\
\hline
\end{tabular}


Table. 3. N-Gain Data on Prestest and Postest Learning Outcomes

\begin{tabular}{lcccl}
\hline Student & Pretest scores & Postest scores & N-gain & Category \\
\hline Student 1 & 60 & 85 & 0,6 & Medium \\
\hline Student 2 & 95 & 100 & 1,0 & High \\
\hline Student 3 & 50 & 80 & 0,6 & Medium \\
\hline Student 4 & 45 & 75 & 0,5 & Medium \\
\hline Student 5 & 65 & 80 & 0,4 & Medium \\
\hline Student 6 & 30 & 75 & 0,6 & Medium \\
\hline Student7 & 45 & 90 & 0,8 & High \\
\hline Student 8 & 30 & 70 & 0,6 & Medium \\
\hline Student 9 & 20 & 75 & 0,7 & Medium \\
\hline Student 10 & 25 & 70 & 0,6 & Medium \\
\hline Mean & $\mathbf{4 6 , 5}$ & $\mathbf{8 0}$ & $\mathbf{0 , 6 5}$ & Medium \\
\hline
\end{tabular}

Table. 4. The Result of Paired Sample Test

Paired Samples Test

\begin{tabular}{|c|c|c|c|c|c|c|c|c|c|}
\hline & & \multicolumn{5}{|c|}{ Paired Differences } & $\mathrm{t}$ & $\mathrm{df}$ & Sig. (2-tailed) \\
\hline & & \multirow[b]{2}{*}{ Mean } & \multirow{2}{*}{$\begin{array}{c}\text { Std. } \\
\text { Deviation }\end{array}$} & \multirow{2}{*}{$\begin{array}{l}\text { Std. Error } \\
\text { Mean }\end{array}$} & \multicolumn{2}{|c|}{$\begin{array}{c}95 \% \text { Confidence Interval } \\
\text { of the Difference }\end{array}$} & & & \\
\hline & & & & & Lower & Upper & & & \\
\hline \multirow[t]{2}{*}{ Pair 1} & Pretest - & - & & & & & & & \\
\hline & Postest & $\begin{array}{r}33,500 \\
00\end{array}$ & 15,46501 & 4,89047 & $-44,56300$ & $-22,43700$ & $-6,850$ & 9 & ,000 \\
\hline
\end{tabular}

\section{Discussion}

This study aims to develop blended learning using the Moodle system in the innovation subject and the educational paradigm to improve student learning outcomes and learning motivation. The use of interactive videos in learning materials can improve learning outcomes and student motivation. In accordance with research [7] which states that interactive video is better in learning and the learning process is faster, so it is effectively used in learning. Another study stated [8] Students in an e-learning environment that provided interactive video achieved significantly better learning performance and higher levels of learner satisfaction than those in other settings.

There are also studies that have found an increase in student learning motivation due to the application of blended learning and an increase in student learning outcomes due to the application of blended learning [9]. Blended learning is a learning model that can increase the attractiveness of the faceto-face learning process and is very suitable to be applied in the 21st era. Blended learning can accommodate broad technological developments without having to abandon face-to-face learning in class by combining face-to-face learning with elearning. Blended learning enables students to continue learning and follow the learning process. This can be an opportunity for the success of teachers and students in learning. Blended learning also helps teachers prepare students to create learning environments according to the learning styles of each student and can help students face challenges in the future and during a pandemic like today [10].

Another study also said that the quality of elearning improves the audio video $\mathrm{CD}$ signal reproduction tool developed "feasible" to use in learning because it is in the "good" category, with a 
mean result of all tests carried out of 4.00 [11]. The effectiveness of moodle-based e-learning as a medium for managing learning in Educational Technology courses is in the good category with an average score of 84.52 [12]. According to the case study at SMKN 1 Lintau Buo, the use of e-learning as a learning medium can increase student learning activities [13].

This also happened in a study [14] that the use of Moodle-based e-learning with the Guided Inquiry approach was effective on learning outcomes. The development of blended learning models based on web and augmented reality can help students to be freer in accessing material at any time. Learning through blended learning based on web and augmented reality can help foster a disciplined, honest and responsible attitude. Learning through blended learning based on web and augmented reality which is presented with interactive technology content can facilitate students in understanding the concept of learning [15].

From the table 3 , it can be concluded that the average pretest is 46.5 and pos-test is 80 . This evaluation also looks at the gain value between the pretest and posttest to see the effectiveness of moodle-based blended learning in the innovation and educational paradigm subjects. There is a significant difference in early learning motivation and late learning motivation from the questionnaire given to students. And from the results of different tests carried out with $\alpha=0.05$ or $5 \%$ Sig (2-tail) the value was 0.0001 . results $0.0001<0.05$, this indicates that there is a significant difference between learning outcomes of innovation subjects and educational paradigms using blended learning using the Moodle e-learning system based on pretest and posttest learning outcomes. The final motivation to learn also has increased significantly.

\section{CONCLUSION AND SUGGESTION}

\section{Conclusion}

Online Learning based on the Moodle University of Bengkulu E-learning System in the Innovation and New Paradigm of Education Subject in the Education Management Postgraduate Program at the University of Bengkulu has been implemented. There are differences in learning outcomes and student learning motivation in the Innovation and New Paradigm of Education Subject in the Educational Administration Master Program at Bengkulu University by using blended learning e-learning. The results of different tests carried out showed a significance level of 0.0001 . This means that there is an effect of blended learning using the e-learning system on learning outcomes and student learning motivation in innovation and educational paradigm subjects.

\section{Suggestion}

We have entered the era of the industrial revolution 4.0. Mastery of technology and innovation in the educational aspect is absolutely necessary. It is hoped that in the future the application of blended learning will not only be applied to innovation subjects and educational paradigms, but can be applied to other subjects. To test the effectiveness of this development, experimental research on the application of blended learning is needed.

\section{REFERENCES}

[1] Risdianto. E. (2019). Analisis pendidikan indonesia di era revolusi industri 4.0. retrieved from

https://www.academia.edu/38353914/analisis_p endidikan_indonesia_di_era_revolusi_industri_ 4.0.pdf

[2] Sugiyono. (2016). Metode Penelitian Kuantitatif, Kualitatif dan R\&D. Bandung: PT Alfabet.

[3] Mulyatiningsih. (2014). Metode Penelitian Terapan Bidang Pendidikan. Bandung : Alfabeta.

[4] Trianto. (2010). Model pembelajaran terpadu. Jakarta : Bumi Aksara.

[5] Meltzer, D.E. (2002). The relationship between mathematics preparation and conceptual learning gains in physics: a possible "hidden variable" in diagnostic pretest scores. AJP, vol 70-125. Https:doi.org/DOI:10.1119/1.1514215

[6] Carman, J. M. (2005). Blended Learning design: five key ingredients. Retrieved November 12, 2018, from https://www.it.iitb.ac.in/ s1000brains/rswork/d okuwiki/media/5_ingredientsoftblended_learnin g_design.pdf

[7] Izzudin, ahmad M., Masugiono, \& Agus Suharmanto. (2013). Efektivitas Penggunaan Media Pembelajaran Video Interaktif Untuk Meningkatkan Hasil Belajar Praktik Service Engine Dan Komponen-Komponennya. Jurusan Teknik Mesin, Fakultas Teknik, Universitas Negeri Semarang, Indonesia.

[8] Zhang, D., Zhou, L., Briggs, R. O., \& Nunamaker, J. F. (2006). Instructional Video in E-Learning: Assessing the Impact of Interactive Video on Learning Effectiveness. Information \& Management, 43(1), 15-27. https://doi.org/10.1016/j.im.2005.01.004

[9] Sjukur, S. B. (2012). Pengaruh blended learning terhadap motivasi belajar dan hasil belajar siswa di tingkat SMK. Jurnal pendidikan vokasi, 2(3). 
[10] Wardani, Deklara Nanindya, Anselmus J.E. Toenlioe., Agus Wedi. (2018). Daya tarik pembelajaran di era 21 dengan blended learning. JKTP Volume 1, Nomor 1.

[11] Zyainuri, Marpanaji, Eko. (2012). Penerapan ELearning Moodle Untuk Pembelajaran Siswa Yang Melaksanakan Prakerin. Jurnal Pendidikan Vokasi, Vol 2, No 3, 368-378.

[12] Hakim, Arif Rahman. (2018). Pengembangan E-Learning Berbasis Moodle Sebagai Media Pengelolaan Pembelajaran. Kodifikasia, Volume 12, No. 2.

[13] Utami, Iga Setia. (2016). Implementasi ELearning untuk Meningkatkan Aktivitas Belajar Siswa. Jurnal Komputer Terapan, Vol.2, No. 2, 169-178.
[14] Muazizah, Noor Malikhah, Sri Nurhayati, dan Edy Cahyono. (2016). Keefektifan penggunaan e-learning berbasis moodle berpendekatan guided inquiry terhadap hasil belajar siswa. Jurnal Inovasi Pendidikan Kimia, Vol 10, No. 2, 2016, $1760-1768$.

[15] Risdianto, E. (20191). Development of Blended Learning Based on Web and Augmented Reality. In International Conference on Educational Sciences and Teacher Profession (ICETeP). Advances in Social Science, Education and Humanities Research, volume 295, pp. 144-147. Atlantis Press. 